\title{
Adenomyoma of the Small Intestine: Case Report
}

\author{
İnce Barsakta Adenomyom: Olgu Sunumu
}

\author{
Cevriye CANSIZ1', Gülşah KAYGUSUZ1', Işınsu KUZU' ', Şiyar ERSÖZ², Selçuk HAZiNEDAROĞLU²
}

Department of ${ }^{1}$ Pathology and ${ }^{2}$ General Surgery, Ankara University, Faculty of Medicine, ANKARA, TURKEY

\begin{abstract}
Adenomyoma of the small intestine is a rare entity characterized by a mixture of glandular structures with intervening bundles of smooth muscle. It occurs mostly in the periampullary region or ileum. Seven cases of jejunal adenomyoma have previously been reported in the literature. We describe here a 61-year-old male suffering from an inguinal hernia with a polipoid lesion in the submucosa of the jejunum strangulated in hernisac.
\end{abstract}

Key Words: Jejunum, Adenomyoma, Inguinal hernia
ÖZ

İnce barsakta adenomyoma nadir görülen bir antite olup, glanduler yapılar ve bunların arasına giren düz kas demetlerinin varlığı ile karakterlidir. Büyük oranda periampuller bölge veya ileumda görülür. Literatürde yedi jejunal adenomyoma olgusu bildirilmiştir. Biz burada, inguinal hernisi olan 61 yaşındaki bir erkek hastada herni içerisindeki jejunum submukozasında polipoid lezyon ile karakterize bir olguyu sunmaktayız.

Anahtar Sözcükler: Jejunum, Adenomyom, İnguinal herni

\section{INTRODUCTION}

Adenomyoma is a rare benign lesion of hepatobiliary and gastrointestinal tracts. Most of them have been described in the gallbladder. A few cases have been reported elsewhere in the gastrointestinal tract including the ampullary region, small bowel and stomach $(1,2,13,25)$. Adenomyoma of the small intestine distal to the duodenum is very rare. To date, only 26 cases have been reported in the literature.

\section{CASE REPORT}

A 61-year-old male was admitted to the Department of General Surgery due to lower abdominal pain. He had a history of reducible inguinal hernia for two years. Partial small intestinal resection and primary hernia repair were performed. He was discharged from the hospital a week later.

Macroscopically, there was a $2.5 \times 1 \times 1 \mathrm{~cm}$ nodular, solid submucosal lesion in the small intestine. Ischemic changes were detected in the intestinal wall. Microscopically, the lesion was located within the mucosa and submucosa. It was composed of glandular structures of variable size and shape. There were irregular muscular bundles surrounding the glandular structures (Figure 1A,B). The glandular structures were lined by cuboidal or tall columnar

Received : 23.03.2009

Accepted : 07.05.2009 epithelium with regular basally located nuclei and without atypia or mitotic activity (Figure 1C). There were no pancreatic acini or islets. We did not observe Paneth cells or goblet cells. Immunohistochemistry was performed using antibodies against CK7 (OV-TL12/30, Neomarkers, CA, USA 1:150), SMA (1A4, 1:300 Neomarkers, CA, USA) and CK20 (Ks20.8, 1:100 Neomarkers, CA, USA). Immunohistochemistry revealed that SMA was positive in the smooth muscle fibers surrounding the glandular structures (Figure 1D) while CK7 was diffusely positive in the epithelium lining the glands (Figure 1E) and CK20 was negative (Figure $1 \mathrm{~F}$ ).

\section{DISCUSSION}

Adenomyoma is a lesion that is characterized by a mixture of glandular structures surrounded by smooth muscle fibers. It has several synonyms such as myoepithelial hamartoma $(1,2,12,13,15)$, adenomyomatous hamartoma $(4,8)$ and foregut choristoma (6). Adenomyoma of the small intestine distal to duodenum is very rare. To date, only 26 well documented cases of adenomyoma involving small intestine have been reported in the literature (1-24). Eighteen male and eight female patients ranging in age from 2 days to 82 years have been reported. The lesion frequently causes intussusception, but some cases were

Correspondence: Gülşah KAYGUSUZ

Department of Pathology, Ankara University, Faculty of Medicine, ANKARA, TURKEY

E-mail: gulsah@gmail.com Phone: +90 3123103010 

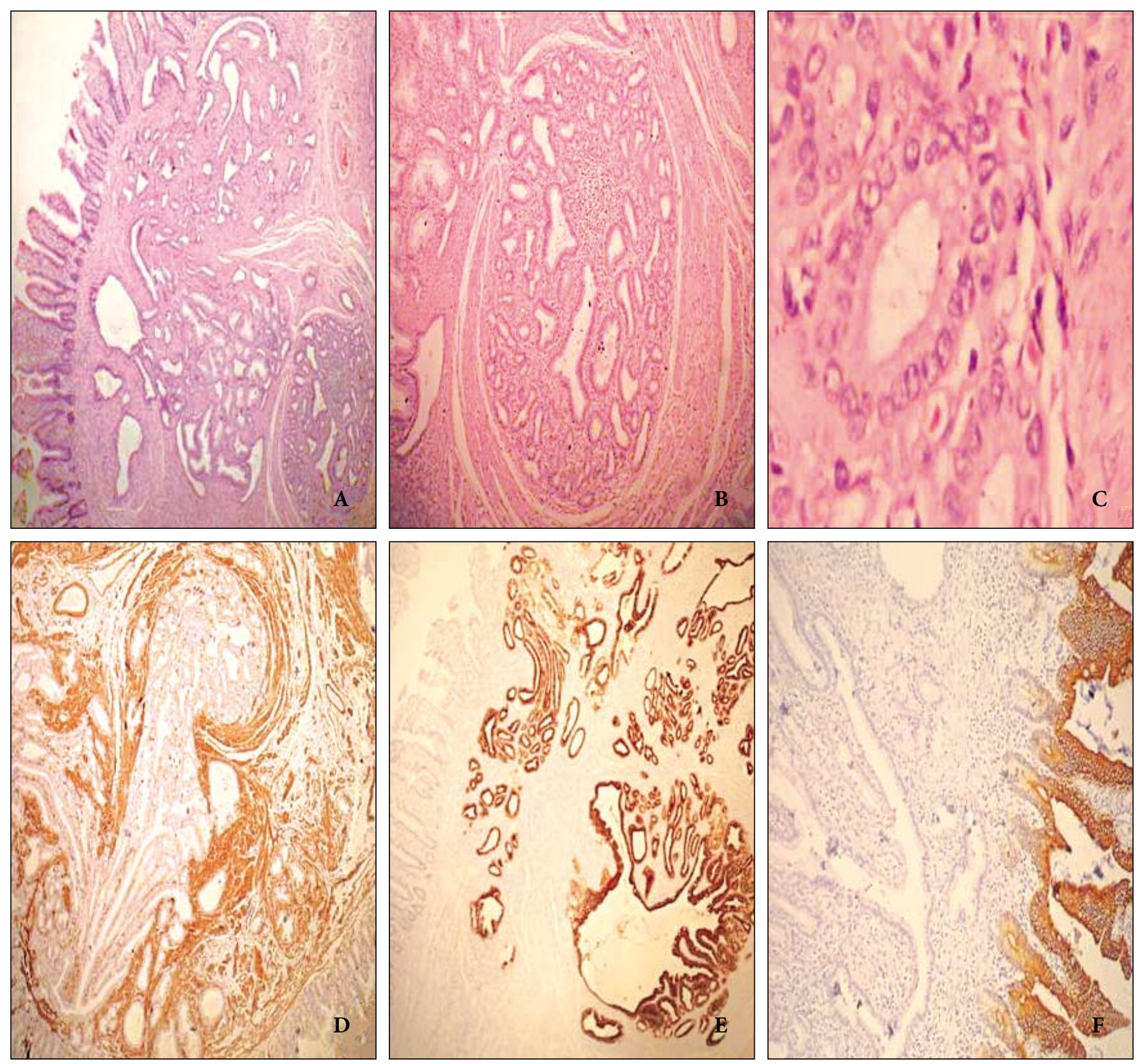

Figure 1: (A-C) Lesion composed of glandular structures with surrounding muscular bundles (H\&E; A, B: x100, C: x400). (D) SMA expression of smooth muscle bundles (x100). (E) CK7 positivity in the glandular epithelium (x100). (F) Lesion was CK20 negative (x200).

described as an incidental finding at surgery or autopsy. One of the reported cases caused gastrointestinal bleeding (24). Although our case had a history of inguinal hernia for two years, strangulation might have been caused by the mass effect of adenomyoma. The diameter of the reported lesions ranged from 0.6 to $6 \mathrm{~cm}$ and they occurred more frequently in the ileum than jejunum. Microscopically, only five of those 22 cases have been reported to contain goblet cells, and one case contained goblet and Paneth cells
(23). We did not see either cells in our case. Only 7 cases of jejunal adenomyoma have previously been reported $(1,5,18,20,24,26)$. The clinicopathological findings of jejunal cases are listed in Table I.

The pathogenesis of adenomyoma of the gastrointestinal tract is not fully understood. It is generally considered to be either a form of hamartoma or a pancreatic heterotopia, but we agree with Clarke's suggestion that the term "adenomyoma" should be used only for lesions with smooth 
Table I: Clinicopathological findings of adenomyoma of the jejunum

\begin{tabular}{|c|c|c|c|c|c|c|}
\hline Case & Sex & Age & $\begin{array}{c}\text { Diameter } \\
(\mathbf{c m})\end{array}$ & Location & Symptoms & References \\
\hline 1 & Male & 64 years & 1 & Jejunum & Incidental & 1 \\
\hline 2 & Male & 18 years & 4.5 & Jejunum & Intussusception & 18 \\
\hline 3 & Male & 63 years & 1.3 & Jejunum & Incidental & 20 \\
\hline 4 & Female & 74 years & 1.5 & Jejunum & Intermittent tarry stool passage & 24 \\
\hline 5 & Unknown & Unknown & Unknown & Jejunum & Unknown & 5 \\
\hline 6 & Unknown & Unknown & Unknown & Jejunum & Unknown & 5 \\
\hline 7 & Female & 61 years & 1.5 & Jejunum & Abdominal pain & 26 \\
\hline
\end{tabular}

muscle and exocrine-type ducts without ectopic pancreatic acini or islets (1). As in our case, CK7 (+) and CK20 (-) expression profile of the glandular element coincides with that of the pancreatic duct epithelium, but not with that of intestinal epithelium. This finding supports the theory of heterotopic pancreas. The presence of smooth muscle tissue might be explained by secondary muscle proliferation caused by stimulus of misplaced epithelium (23). The pathological differential diagnosis must include enteritis cystica profunda, heterotopic pancreas, pneumatosis cystoides intestinalis, metastatic adenocarcinoma and hamartomatous polyp in Peutz-jeghers syndrome. The cysts in enteritis cyctica profunda are not encircled by muscle fibers. They are often confused with metastatic adenocarcinoma. Adenomyoma shows an orderly arrangement or lobular pattern of benign ducts that shows no atypia in a background of proliferating smooth muscle rather than desmoplastic stroma. The orderly arrangement of the two muscle layers around the ducts distinguishes adenomyoma from heterotopic pancreas (25). The cysts with no epithelial lining in pneumatosis cystoides intestinalis contain gas, whereas the glands and cysts of adenomyomas are lined by epithelial cells (23). The important feature in Peutz-Jeghers syndrome is the presence of branching cores of muscular fibers derived from the muscularis mucosa, while adenomyoma is located in the submucosa and/or muscularis propria. The diagnosis can be difficult, especially if the small biopsies come from an adult patient with obstructive symptoms.

In conclusion, this case was important for its unusual clinical presentation and rare location.

\section{REFERENCES}

1. Clarke BE: Myoepithelial hamartoma of the gastrointestinal tract: a report of eight cases with comment concerning genesis and nomenclature. Arch Pathol 1940, 30:143-152

2. Gonzálvez J, Marco A, Andújar M, Iñiguez L: Myoepithelial hamartoma of the ileum: a rare cause of intestinal intussusception in children. Eur J Pediatr Surg 1995, 5:303-304
3. Rosenmann E, Maayan C, Lernau O: Leiomyomatous hamartosis with congenital jejunoileal atresia. Isr J Med Sci 1980,16:775-779

4. Gal R, Kolkow Z, Nobel M: Adenomyomatous hamartoma of the small intestine: a rare cause of intussusception in an adult. Am J Gastroenterol 1986, 81:1209-1211

5. Olmsted WW, Ros PR, Hjermstad BM, McCarthy MJ, Dachman $A H$ : Tumors of the small intestine with little or no malignant predisposition: a review of the literature and report of 56 cases. Gastrointest Radiol 1987, 12:231-239

6. Kim CJ, Choe GY, Chi JG: Foregut choristoma of the ileum (adenomyoma)- a case report. Pediatr Pathol 1990, 10:799-805

7. Gal R, Rath-Wolfson L, Ginzburg M, Kessler E: Adenomyomas of the small intestine. Histopathology 1991, 18:369-371

8. Lamki N, Woo CL, Watson AB Jr, Kim HS: Adenomyomatous hamartoma causing ileoileal intussusception in a young child. Clin Imag 1993,177:183-185

9. Gourtsoyiannis NC, Bays D, Papaioannou N, Theotokas J, Barouxis G, Karabelas T: Benign tumors of the small intestine: preoperative evaluation with a barium infusion technique. Eur J Radiol 1993, 16:115-125

10. Chan YF, Roche D: Adenomyoma of the small intestine in children. J Pediatr Surg 1994, 29:1611-1612

11. Serour F, Gorenstein A, Lipnitzky V, Zaidel L: Adenomyoma of the small bowel: a rare cause of intussusception in childhood. J Pediatr Gastroenterol Nutr 1994, 18,247-249

12. Gonzálvez J, Marco A, Andújar M, Iñiguez L: Myoepithelial hamartoma of the ileum: a rare cause of intestinal intusseption in children. Eur J Pediatr Surg 1995, 5:303-304

13. Tanaka N, Seya T, Onda M, Kanazawa Y, Naitoh Z, Asano G, Hao K: Myoepithelial hamartoma of small bowel: report of a case. Surg Today 1996, 26:1010-1013

14. Hizawa K, Iida M, Aoyagi K, Mibu R, Yao T, Fujishima M: Jejunal myoepithelial hamartoma associated with Gardner's syndrome: a case report. Endoscopy 1996, 28:727

15. Yamagami T, Tokiwa K, Iwai N: Myoepithelial hamartoma of the ileum causing intussusception in an infant. Pediatr Surg Int 1997, 12:206-207

16. van Helden SH, Jutten G, Van Hoey H, Dierick AM: Jejunal hamartoma as a rare cause of gastrointestinal haemorrhage. Histopathology 1998, 32:574-575

17. Yao JL, Zhou H, Roche K, Bangaru BS, Ginsburg H, Greco MA: Adenomyoma arising in a meckel diverticulum: case report and review of the literature. Pediatr Dev Pathol 2000, 3:497-500 
18. Lee JS, Kim HS, Jung JJ, Kim YB: Adenomyoma of the small intestine in an adult: a rare cause of intussusception. J Gastroenterol 2002, 37:556-559

19. Mouravas V, Koutsoumis G, Patoulias J, Kostopoulos I, Kottakidou R, Kallergis K, Kepertis C, Liolios N: Adenomyoma of the small intestine in children: a rare cause of intussusception: a case report. Turk J Pediatr 2003, 45:345-347

20. Park HS, Lee SO, Lee JM, Kang MJ, Lee DG, Chung MJ: Adenomyoma of the small intestine: report of two cases and review of the literature. Pathol Int 2003, 53:111-114

21. Lo Bello Gemma G, Corradino R, Cavuoto F, Motta M: Myoepithelial jejunal hamartoma causing small bowel intussusception and volvolus. Radiol Med 2003, 105:246-249
22. Ikegami R, Watanabe Y, Tainaka T: Myoepithelial hamartoma causing smallbowel intussusception: a case report and literature review. Pediatr Surg Int 2006, 22:387-389

23. Takahashi Y, Fukushima J, Fukusato T, Mori S: Adenomyoma with goblet and Paneth cells of the ileum. Pathol Res Pract 2006, 202:549-553

24. Yu HC, Lo GH, Lai KH, Hsu PI, Chen IS, Hsieh PP: Adenomyoma of the jejunum-a rare cause of gastrointestinal bleeding. J Chin Med Assos 2008, 71:96-99

25. Fenoglio-Preiser CM. Gastrointestinal Pathology, 3rd ed., Philadelphia, Williams and Wilkins, 2008, 314

26. Qing X, Petrie BA, Buslon V, French S: Adenomyoma of the jejunum. Exp Mol Pathol 2009, 86:127-130 